JINOTEP Vol 8 (3) (2021): 277-288

DOI: $10.17977 / \mathrm{um} 031 \mathrm{v} 8 \mathrm{i} 32021 \mathrm{p} 277$

JINOTEP (Jurnal Inovasi Teknologi Pembelajaran) Kajian dan Riset Dalam Teknologi Pembelajaran http://journal2.um.ac.id/index.php/jinotep/index

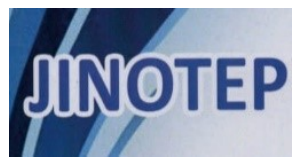

\title{
PENGEMBANGAN SOFTWARE MULTIMEDIA MATA KULIAH LABORATORIUM PEMROGRAMAN DASAR UNTUK MAHASISWA BERKEBUTUHAN KHUSUS
}

\author{
Riki Buldan Al Hariri, Bella Hardiyana, Rani Puspita Dhaniawaty \\ Program Studi Sistem Informasi - Universitas Komputer Indonesia
}

\begin{tabular}{l} 
Article History \\
\hline Received: 06-08-2021 \\
Accepted: 05-10-2021 \\
Published: 01-11-2021 \\
\hline Keywords \\
\hline Aplikasi Multimedia; \\
Android; Pemrograman; \\
Mahasiswa \\
Berkebutuhan Khusus \\
\hline
\end{tabular}

\begin{abstract}
Abstrak
Tujuan penelitian ini untuk menghasilkan aplikasi pembelajaran tentang mata kuliah laboratorium pemrograman dasar berbasis android. Fokus pada penelitian ini menghasilkan multimedia pembelajaran untuk meningkatkan pemahaman dan minat pada mahasiswa berkebutuhan khusus serta membuat alternatif pembelajaran yang menarik. Untuk mengembangkan aplikasi multimedia pembelajaran digunakan metode Lee dan Owens. Penelitian ini bersubjek dari penelitian ini yaitu mahasiswa berkebutuhan khusus pada program studi sistem informasi UNIKOM mata kuliah laboratorium pemrograman dasar. Aplikasi ini diujikan pada 1 ahli media, 1 ahli materi, 1 ahli disabilitas serta 25 mahasiswa reguler dan 5 mahasiswa berkebutuhan khusus. Hasil pengujian dari ahli media senilai $84 \%$, ahli materi $80 \%$, ahli disabilitas $79 \%$ serta respons mahasiswa MBK $81 \%$ dan mahasiswa reguler sebesar $86 \%$. Berdasarkan hasil pengujian, produk ini dapat dikatakan layak untuk digunakan.
\end{abstract}

\begin{abstract}
The purpose of this research is to produce learning applications about basic android-based programming laboratory courses. The focus of this research is to produce learning multimedia to increase understanding and interest in students with special needs and to create interesting learning alternatives. To develop learning multimedia applications, the Lee and Owens method is used. The subjects of this study were students with special needs in the UNIKOM information systems study program for basic programming laboratory courses. This application was tested on 1 media expert, 1 material expert, 1 disability expert and 25 reguler students and 5 students with special needs. The test results from media experts are $84 \%$, material experts are $80 \%$, disability experts are $79 \%$ and the response of $M B K$ students is $81 \%$ and reguler students are $86 \%$. Based on the test results, this product can be said to be feasible to use.
\end{abstract}

Corresponding author:

Riki Buldan Al Hariri

Sistem Informasi FTIK Universitas Komputer Indonesia

Jalan Dipati Ukur No.112-116, Bandung 40132 Indonesia

Email: rickybuldan99@mahasiswa.unikom.ac.id
2021 Universitas Negeri Malang p-ISSN 2406-8780 e-ISSN 2654-7953 
278 JINOTEP (Jurnal Inovasi dan Teknologi Pembelajaran) Kajian dan Riset dalam Teknologi Pembelajaran Vol.8, No.3, November 2021, Hal. 277-288

\section{PENDAHULUAN}

Pendidikan merupakan hal terpenting dalam kehidupan, karena dengan pendidikan manusia dapat berkembang dan menghadapi era teknologi yang canggih. Individu juga membutuhkan pendidikan untuk mengembangkan potensi dirinya dan mempersiapkan individu untuk menghadapi kehidupan sosial. Definisi dari pendidikan atau edukasi merupakan bagian atau bidang yang dapat membuat negara menjadi lebih baik (Akbarini, Murtini, \& Rahmanto, 2018). Pendidikan juga memiliki peran penting dalam membangun masa depan atau terus-menerus berkelanjutan (Nasibulina, 2017). Pendidikan diartikan usaha yang dikerjakan oleh orang untuk memelihara dan meningkatkan bakat yang baik secara fitrah (Djamaluddin, 2014). Untuk membantu proses Pendidikan dibutuhkan media pembelajaran. Media pembelajaran merupakan sebagai bagian dalam lingkungan sekitar belajar yang memberikan keahlian pengguna ketika melihat material pembelajaran dengan cara demokratis (Praherdhiono, 2014). Peran media dalam mata kuliah sangatlah penting. Penyajian media pembelajaran sangat dibutuhkan dengan begitu pembelajaran lebih menarik dan interaktif seperti dengan penggunaan elemen multimedia berupa teks, gambar, suara dan video serta animasi (Purwanto \& Hanief, 2016).

Pendidikan merupakan salah satu hak dan kewajiban yang seharusnya dimiliki oleh setiap manusia, yang dalam hal ini tidak memandang ras, budaya maupun keadaan fisik dari setiap individu. Berdasarkan hal tersebut mahasiswa yang memiliki kebutuhan khusus seharusnya lebih diperhatikan dari orang pada umumnya.
Pendidikan juga dapat memanfaatkan elemen yang ada pada multimedia dengan begitu pembelajaran dapat menjadi lebih baik dan memudahkan dalam proses pendidikan itu sendiri. Dengan adanya elemen multimedia tersebut dapat menunjang pembelajaran yang lebih menarik dan interaktif, bermanfaat bagi dunia pendidikan itu sendiri dengan cara memanfaatkan teknologi yang ada.

Mata kuliah laboratorium pemrograman dasar merupakan salah satu materi wajib pada program studi sistem informasi. Mata kuliah ini merupakan materi praktikum dari mata kuliah algoritma dan pemrograman dasar. Kedua materi ini saling keterkaitan berupa teori sebagai materi algoritma pemrograman dasar dan praktikum sebagai laboratorium pemrograman dasar.

Ilmu awal atau dasar bagi seorang mahasiswa yang mengikuti kuliah di program studi sistem informasi yaitu ilmu laboratorium pemrograman dasar. untuk mempelajari ilmu pemrograman ke level yang lebih tinggi dibutuhkan materi dasar pemrograman. Dalam materi ini berisi tata cara dalam penulisan perintah pada program (syntax) adalah materi Laboratorium pemrograman dasar yang dibuat sebagai aplikasi pembelajaran.

Aplikasi pembelajaran tersebut ditujukan sebagai salah satu alternatif untuk media pembelajaran, agar menarik minat dan meningkatkan pemahaman mahasiswa berkebutuhan khusus. Selain itu juga mempermudah mahasiswa berkebutuhan khusus untuk menikmati proses pembelajaran.

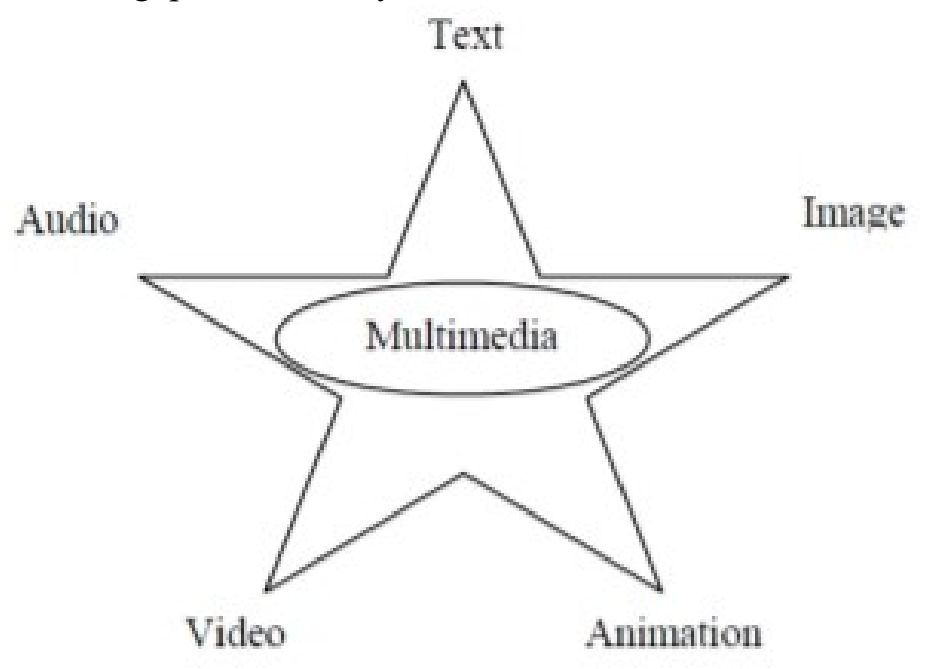

Gambar 1. Elemen Multimedia 
Materi tentang pemrograman khususnya materi laboratorium pemrograman dasar dirasa cukup sulit bagi mahasiswa berkebutuhan khusus. Mahasiswa berkebutuhan khusus memerlukan media pembelajaran yang interaktif untuk menunjang proses belajarnya. Maka dari itu materi laboratorium pemrograman dasar dibuat sedemikian rupa menyesuaikan kemampuan mahasiswa berkebutuhan khusus dalam memahami materinya melalui teknologi mobile.

Pembelajaran menggunakan elektronik merupakan pembelajaran yang dilakukan dari media elektronik (Kaewkiriya, 2013). Pembelajaran berbantuan komputer multimedia menjadi peran yang penting dalam pembelajaran (Shi, 2017). Membuat sebuah media pembelajaran atau game yang dapat mempermudah pengajar pada saat menyampaikan materi perkuliahan kepada mahasiswa berkebutuhan khusus (Fadillah, Hardiyana, \& Dhaniawaty, 2021).

Perkembangan teknologi mobile memiliki perkembangan yang begitu cepat. Bermacam perangkat mobile yang telah dibuat, sebagai contoh ponsel. Ponsel merupakan salah satu perangkat mobile berbasis teknologi yang tercepat dalam perkembangannya di dunia (Sambung, Sihkabuden, \& Ulfa, 2018).

Dalam segi penggunaan, aplikasi pembelajaran laboratorium pemrograman dasar berbasis android hanya perlu memakai teknologi seluler berupa ponsel dengan sistem operasi yang tergolong android minimal versi 6.0 dan spesifikasi yang tidak terlalu tinggi dalam menjalankannya. Sehingga akan membuat mahasiswa khususnya mahasiswa berkebutuhan khusus menjadi lebih praktis dan lebih interaktif.

Multimedia interaktif yaitu multimedia dilengkapi dengan alat pengatur dan bisa dioperasikan atau digunakan oleh pengguna, dengan begitu dapat mengikuti keinginan atau kehendak pengguna untuk proses selanjutnya (Gunawan, 2015). Penggunaan aplikasi berbasis android ini juga dirasa cukup memungkinkan dikarenakan penggunaan smartphone berbasis android terutama yang digunakan oleh mahasiswa berkebutuhan khusus hampir semuanya memiliki dan dapat menggunakan smartphone tersebut.
Penelitian ini dilakukan mengingat kurangnya perlakuan khusus pada mahasiswa berkebutuhan khusus di dalam proses pembelajaran. Pembelajaran alternatif dibutuhkan mengingat mahasiswa berkebutuhan khusus memiliki keterbatasan. Akibat dari kurangnya alternatif pembelajaran dapat menghambat pemahaman dari mahasiswa berkebutuhan khusus itu sendiri. Dengan adanya aplikasi alternatif ini dapat membantu pemahaman pada mahasiswa berkebutuhan khusus itu sendiri. Dengan begitu tujuan penelitian ini selain menghasilkan aplikasi sebagai alternatif pembelajaran juga dapat membantu mahasiswa berkebutuhan khusus dalam proses belajar.

\section{METODE}

Perancangan menggunakan metode Lee dan Owens yang diantaranya tahapan metode tersebut yaitu analisis/analysis, desain/design, dan pengembangan atau development, implementasi/implementation, dan terakhir yaitu evaluasi/evaluation (Lee \& Owens, 2004).

Berikut tahapan pengembangan model pengembangan yang digunakan dalam penelitian adalah sebagai berikut:

\section{Analisis}

Dari analisis yang dilakukan didapatkan dari kegiatan belajar mengajar yang ada di mata kuliah laboratorium pemrograman dasar pada program studi sistem informasi. Kegiatan belajar mengajar meliputi pembelajaran langsung dan pembelajaran tak langsung. Pembelajaran langsung dilakukan melalui online dengan menggunakan aplikasi conference seperti aplikasi zoom dan google meet dan juga pembelajaran tak langsung melalui LMS (Learning Management System) UNIKOM dengan pembelajaran yang menyetarakan keseluruhan mahasiswa. Dalam kasus ini adanya mahasiswa berkebutuhan khusus yang seharusnya dalam proses pembelajaran itu sendiri harus diperlakukan secara khusus.

\section{Design}

Dalam tahap design, aplikasi pembelajaran laboratorium pemrograman dasar berasal dari materi Tim Multimedia Algoritma dan pemrograman dasar dan membuat video tutorial tentang algoritma dan pemrograman dasar. yang 
280 JINOTEP (Jurnal Inovasi dan Teknologi Pembelajaran) Kajian dan Riset dalam Teknologi Pembelajaran Vol.8, No.3, November 2021, Hal. 277-288

berjumlah tujuh materi yaitu, pengenalan Bahasa C, penggunaan tipe data, fungsi input dan output, Selection atau seleksi, Perulangan atau Looping, larik atau Array, dan terakhir yaitu Struct dalam Bahasa C. Alat bantu untuk membuat desain adalah dengan menggunakan storyboard yang akan dijelaskan pada bagian hasil.

\section{Pengembangan dan Pelaksanaan}

Pembuatan aplikasi yang dilakukan berdasarkan storyboard yang sudah dirancang sebelumnya. Piranti lunak Unity 2019 digunakan sebagai pengembangan aplikasi dan piranti lunak Adobe Illustrator 2020 digunakan untuk pembuatan resource berupa design gambar yang akan dimasukkan ke dalam aplikasi. Hingga diakhir akan dilakukan pengujian aplikasi dengan menggunakan metode blackbox. Pengujian Blackbox testing dilakukan hanya dengan memperhatikan hasil eksekusi dari data yang diuji dan mengecek kegunaan dari perangkat lunak. (Astuti, 2018).

Untuk tahap pengimplementasian akan diuji oleh pembuat aplikasi, seorang ahli materi serta ahli media. Setelah itu dilakukan pengujian pada mahasiswa berkebutuhan khusus yang berjumlah 5 mahasiswa dan mahasiswa reguler 25 orang.

\section{Evaluasi}

Evaluasi merupakan suatu kegiatan untuk mengukur suatu sesuatu atau keadaan sehingga menghadirkan suatu informasi berupa nilai sebagai alternatif dalam mengambil keputusan (Ambiyar \& Dewi, 2019). Mengukur validitas produk yaitu untuk mengetahui apakah media pembelajaran berupa aplikasi ini cocok atau tidak digunakan untuk alternatif pembelajaran. Untuk pengujian sendiri dilakukan satu orang dosen yang ahli dalam media, satu orang dosen yang ahli dalam materi dan 25 mahasiswa. Serta mahasiswa berkebutuhan khusus sebanyak 5 orang yang mengikuti mata kuliah laboratorium pemrograman dasar.

\section{HASIL}

Desain yang dipilih adalah bertemakan pemandangan gurun, yang didesain sedemikian rupa, dengan mengkombinasikan warna yang sesuai serta animasi yang sesuai yang membuat tampilan lebih menarik, sehingga dapat menambah minat belajar bagi mahasiswa khususnya mahasiswa berkebutuhan khusus yang mengikuti mata kuliah laboratorium pemrograman dasar pada program studi sistem informasi UNIKOM. Dari tahap desain yang dilakukan, menghasilkan sebuah rancangan desain dengan alat bantu berupa storyboard.

Berikut ini adalah gambar atau perancangan desain, yang dihasilkan melalui storyboard yang telah dibuat:

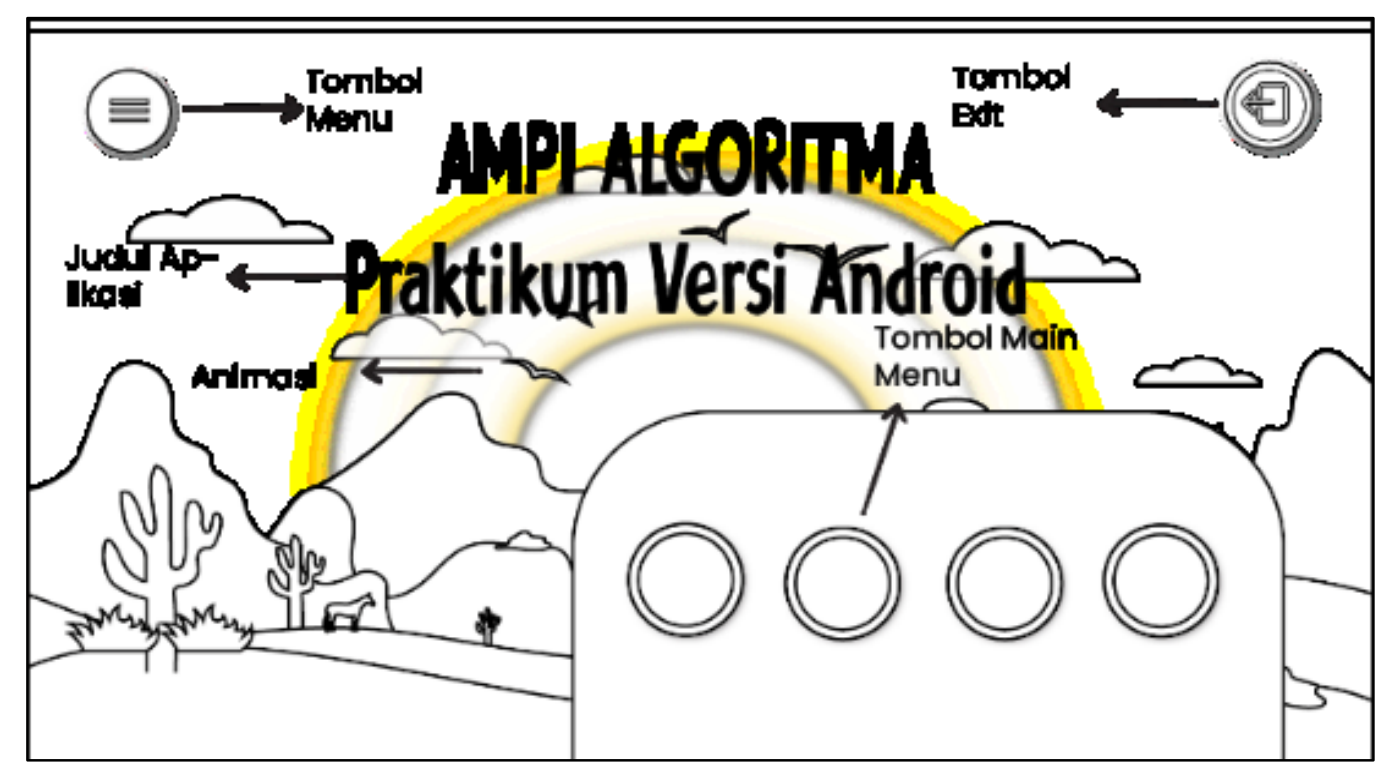

Gambar 2. Rancangan Main Menu 


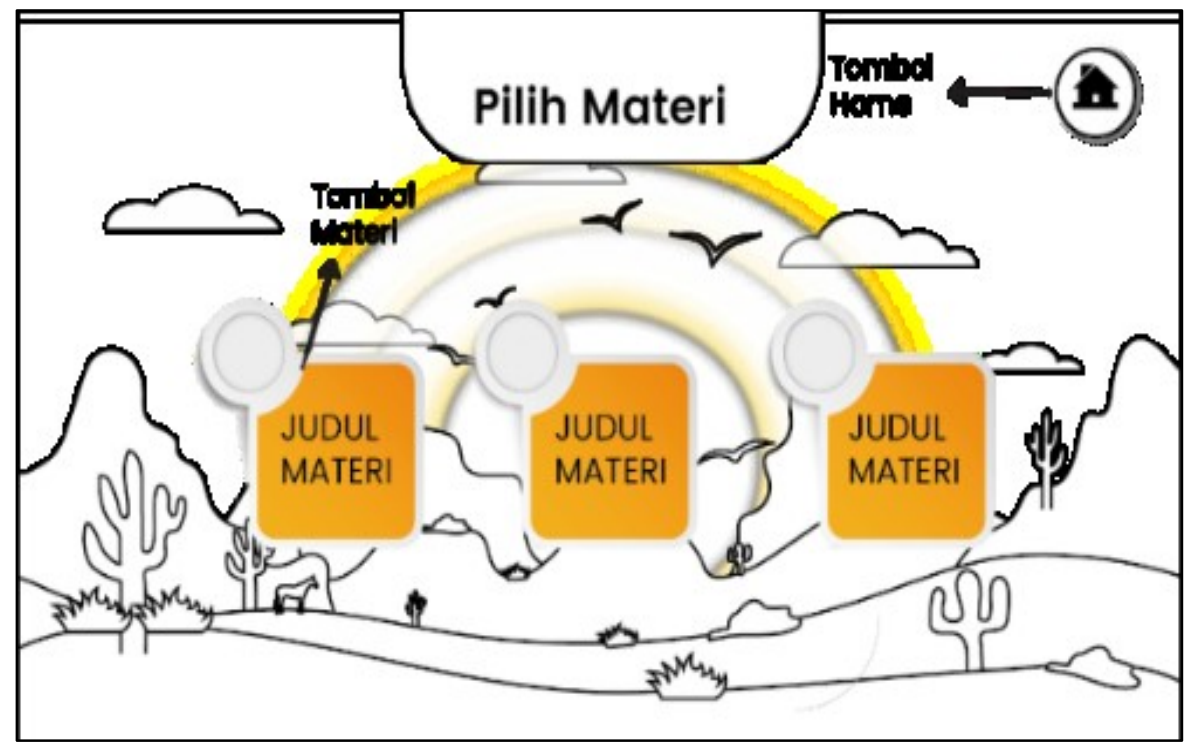

Gambar 3. Menu Materi

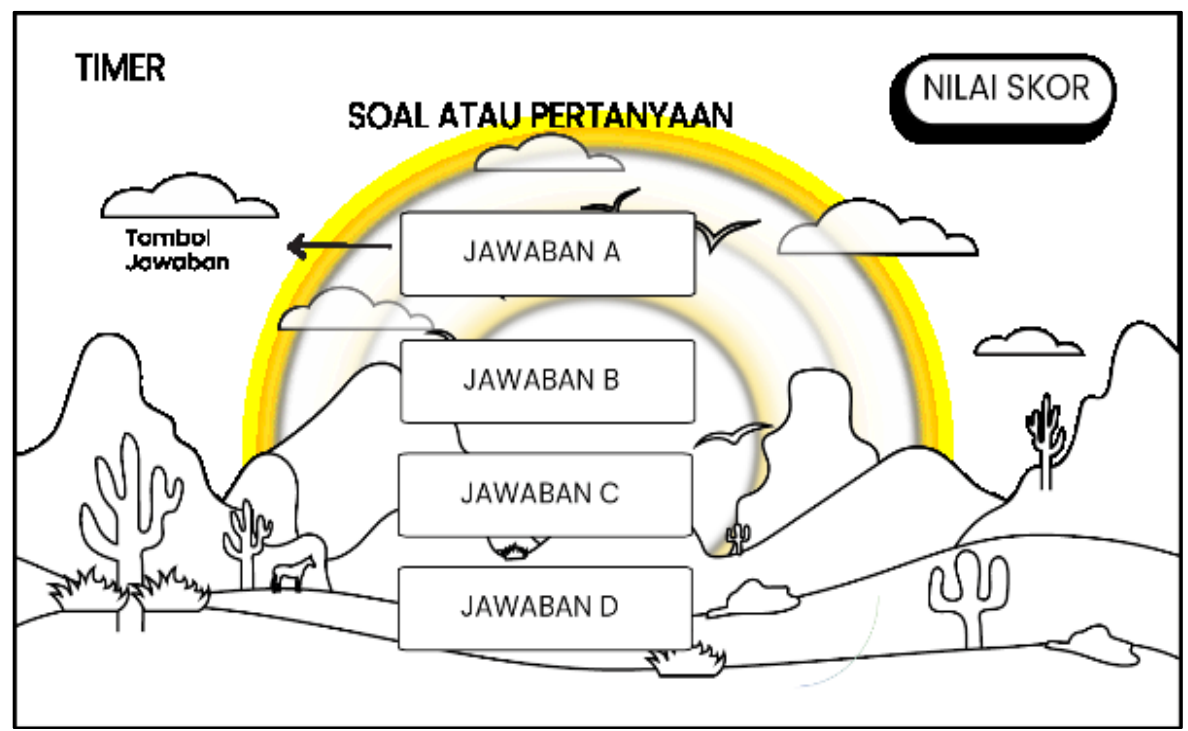

Gambar 4. Menu Kuis

Berikut adalah user interface aplikasi yang dibuat berdasarkan storyboard yang sudah dirancang:

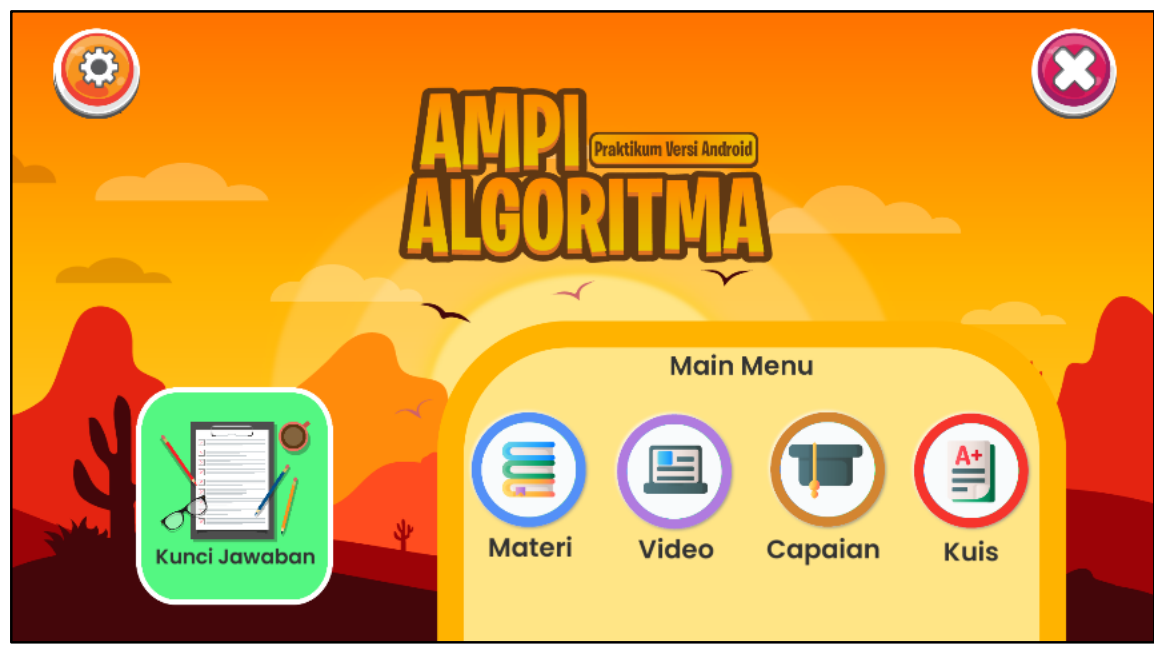

Gambar 5. Main Menu 


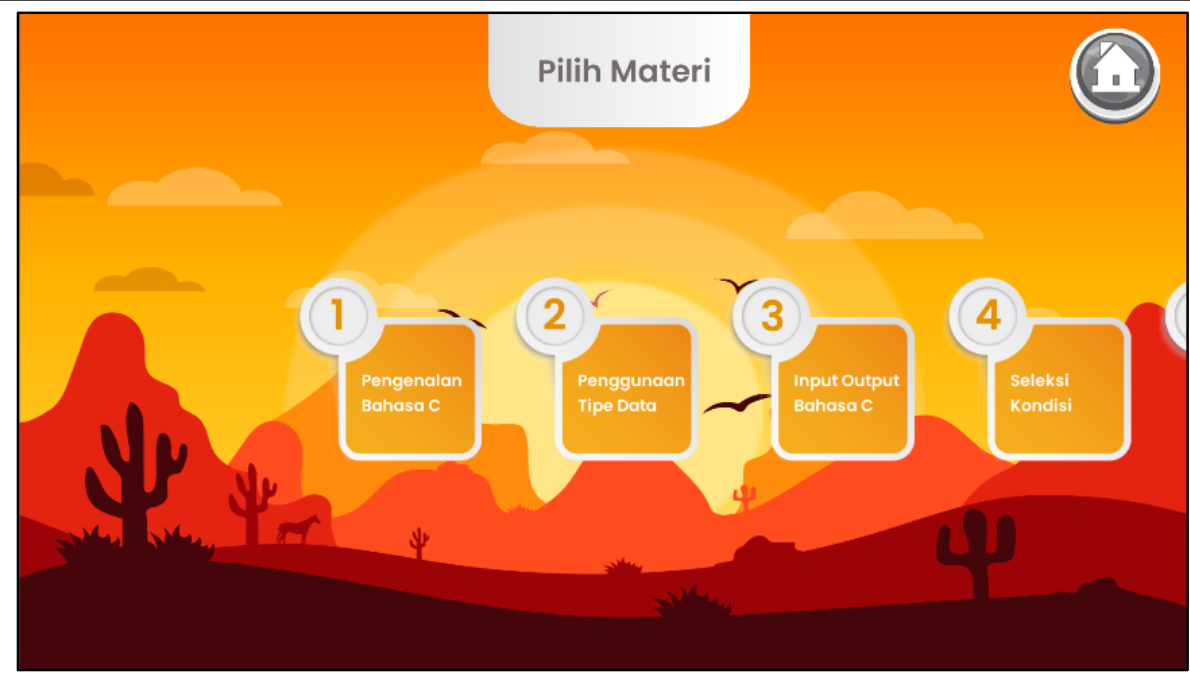

Gambar 6. Menu Materi

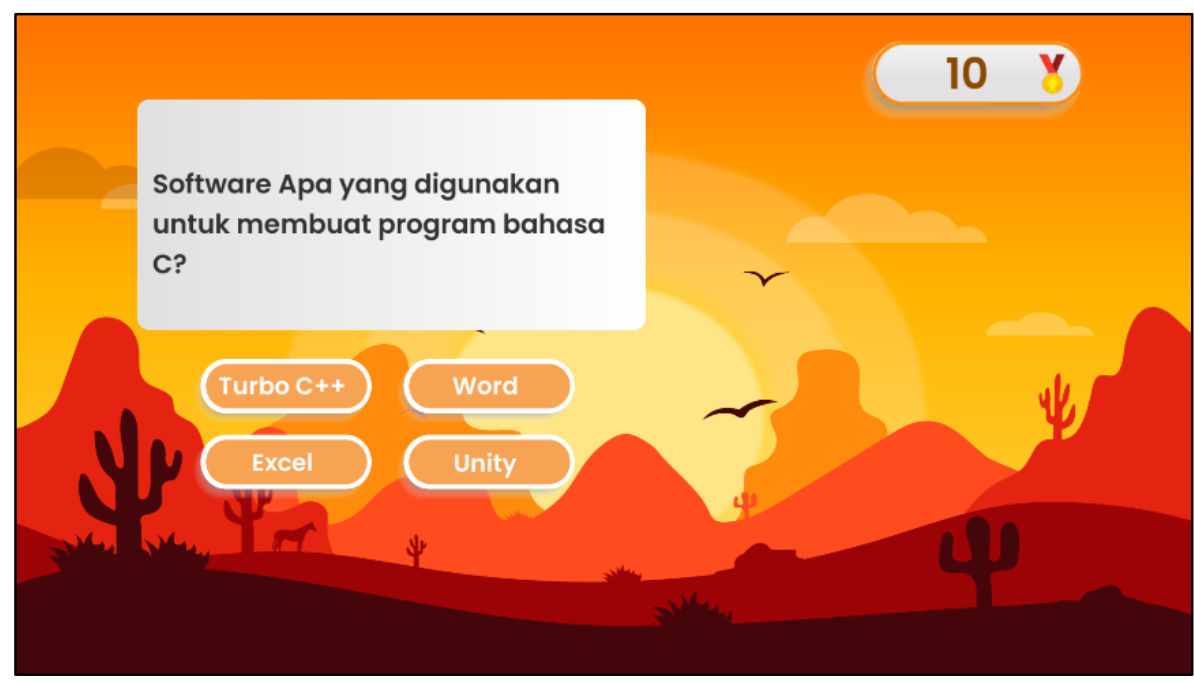

Gambar 7. Menu Kuis

Dalam aplikasi terdapat menu-menu ataupun fitur utama, yaitu seperti menu kuis, simulasi ujian, dan menu materi serta menu video. Selain itu juga ditambahkan elemen multimedia seperti animasi yang sudah disesuaikan dan juga dibuatkan tampilan yang menarik atau tidak membuat jenuh serta membuat pembelajaran fleksibel karena menggunakan smartphone dalam pengoperasiannya, sehingga pembelajaran menjadi lebih menyenangkan Terdapat beberapa struktur menu pada aplikasi pembelajaran laboratorium pemrograman dasar adalah sebagai berikut:

1. Menu Profil

Terdapat tombol simpan yang berfungsi untuk menyimpan nama, kelas dan nim untuk masuk ke main menu dan juga sebagai halaman biodata pada halaman profil pada main menu.

\section{Main Menu}

Sebagai scene menu utama yang terdapat 6 tombol materi, video, capaian, quis, keluar dan menus halaman menus terdiri dari tombol suara, skor, serta info yang berisi petunjuk dan tentang. Pada main menu juga ditambahkan kunci jawaban agar mahasiswa dapat melihat pembahasan dari pertanyaan kuis.

3. Menu Materi

Di dalam menu ini terdapat 7 tombol menu materi yang bisa diswipe. materi berasal dari materi yang disusun oleh tim dosen algoritma dan laoratorium pemrograman dasar.

\section{Menu Video Praktikum}

Menampilkan 7 video materi praktikum yang dibuat oleh tim dosen Laboratorium 
Pemrograman Dasar UNIKOM. Mulai dari materi pengenalan Bahasa $\mathrm{C}$ hingga Struct. Materi ini berisi video praktikum yang berisi tutorial dan tata cara penggunaan syntax dalam Bahasa C.

\section{Menu Kuis}

Terdapat berisi 7 kuis yang diambil dari masing-masing 7 materi. Kuis tersebut berasal dari materi yang ada di aplikasi yang disusun oleh tim dosen algoritma dan laboratorium pemrograman dasar. Pada menu 1 kuis terdapat variasi soal yaitu, kuis multiple choice, drag and drop, true or false dan juga isian singkat.

\section{Menu Simulasi Ujian}

Terdapat 3 tingkat kesulitan pada menu ini, yaitu mudah, sedang dan juga sulit. Pada simulasi ini merupakan simulasi ujian dari keseluruhan materi yang ada di aplikasi pembelajaran yang dibuat.

Pada tahap hasil dilakukan pengukuran hasil uji coba yang dilakukan pada 25 mahasiswa umum dan 5 mahasiswa berkebutuhan khusus serta dosen yang mengajar mata kuliah Algoritma dan pemrograman dasar sebagai ahli materi. Sedangkan untuk ahli media adalah dosen yang sudah bersertifikasi di bidang multimedia dan animasi.

Setelah melakukan pengukuran, didapatkan hasil analisis dari ahli media didapatkan hasil sebesar $84 \%$. Dengan begitu aplikasi digunakan sebagai alternatif pada media pembelajaran laboratorium pemrograman dasar untuk mahasiswa berkebutuhan khusus yang kemudian diunggah ke dalam LMS UNIKOM.

Analisis data melalui ahli materi mendapatkan hasil sebesar $80 \%$. Dari kriteria yang ditentukan dapat dijelaskan bahwasanya pengembangan multimedia aplikasi tentang mata kuliah laboratorium pemrograman dasar pada program studi sistem informasi UNIKOM tergolong ke dalam valid. Dengan begitu dapat digunakan sebagai alternatif pembelajaran.

Untuk hasil analisis data dari ahli disabilitas didapatkan nilai sebesar 79\%. Hasil ini dapat diartikan bahwa aplikasi multimedia mengenai mata kuliah pemrograman dasar ini dapat digunakan atau dioperasikan oleh mahasiswa berkebutuhan khusus. Dari hasil tersebut menunjukkan produk yang sudah dibuat, termasuk dalam kriteria cocok untuk dioperasikan.

Sedangkan hasil analisis yang didapatkan pada mahasiswa berkebutuhan khusus sebesar $81 \%$ dan juga mahasiswa reguler sebesar $86 \%$. Aplikasi ini termasuk valid dan cocok digunakan pada mahasiswa, khususnya mahasiswa berkebutuhan khusus yang sedang mengikuti Hasil analisis ini juga dapat disimpulkan bahwa aplikasi ini dapat membantu mahasiswa dalam proses pembelajaran materi pemrograman dasar dan dapat meningkatkan motivasi belajar pengguna.

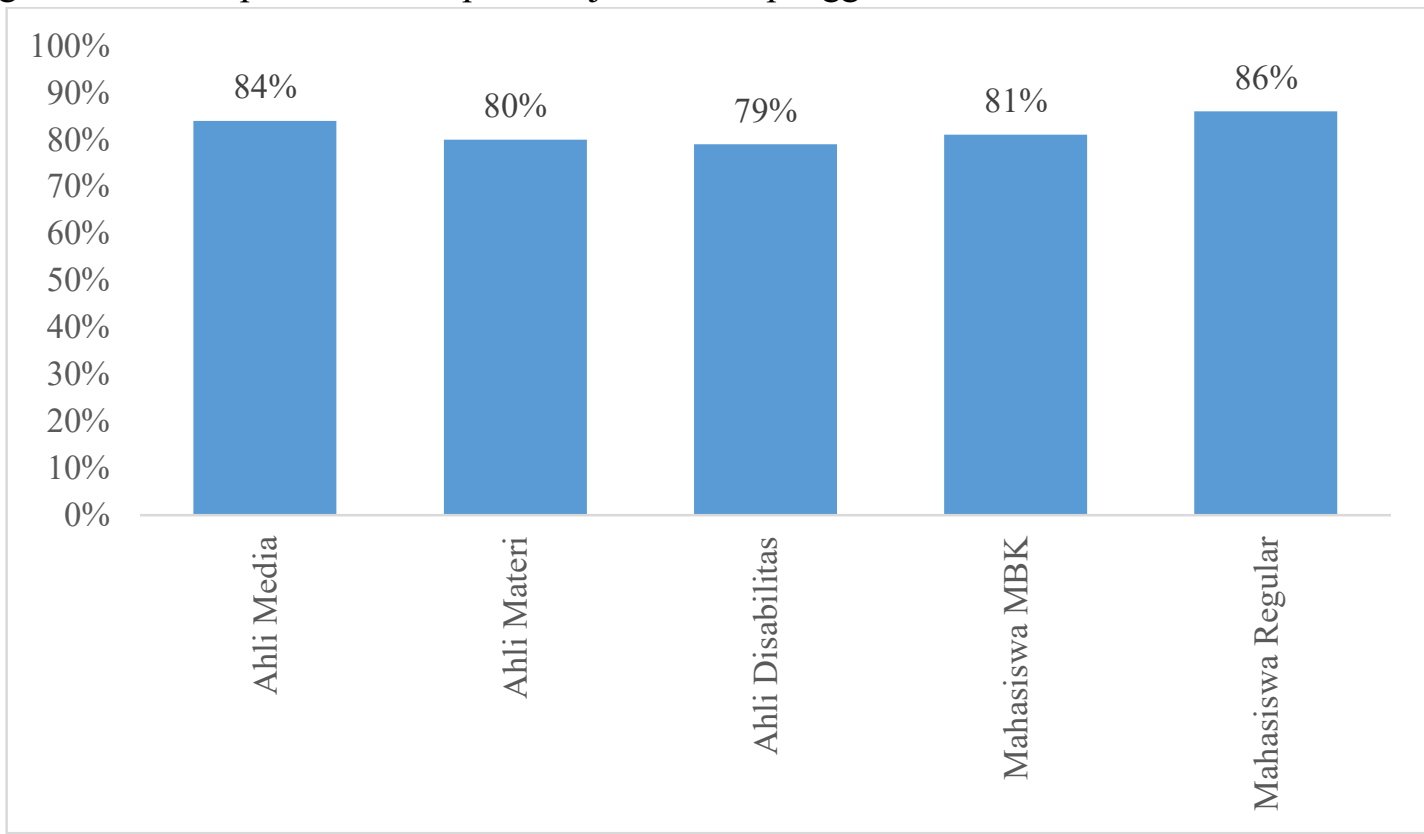

Gambar 8. Data dari ahli dan uji pengguna 
284 JINOTEP (Jurnal Inovasi dan Teknologi Pembelajaran) Kajian dan Riset dalam Teknologi Pembelajaran Vol.8, No.3, November 2021, Hal. 277-288

Untuk mengetahui tingkat atau mengukur tingkat kepuasan pengguna dalam beberapa indikator dalam aplikasi ini, digunakan pengukuran skala likert. Dalam penggunaannya Skala likert memakai butir pertanyaan guna mengukur tingkah laku individu dengan memberikan jawaban 5 titik pilihan pada setiap pertanyaan (Budiaji, 2013).

Hasil dalam penelitian yang dilakukan juga menghasilkan sebuah rancangan atau desain dari aplikasi yang dibuat. Storyboard menjadi alat bantu dalam pembuatan rancangan aplikasi ini. Dikarenakan aplikasi ini berupa multimedia, aplikasi ini didesain dengan cukup menarik agar mahasiswa berkebutuhan khusus ini tidak merasa bosan dengan materi yang disuguhkan serta membuat pembelajaran menjadi lebih bervariasi dalam kegiatan belajar.

Berdasarkan hasil dari tahapan yang dimulai dari hasil analisis hingga pengembangan aplikasi diatas, bahwasanya pengembangan aplikasi multimedia pembelajaran mata kuliah laboratorium pemrograman dasar dapat digunakan sebagai media alternatif pembelajaran berbasis android, yang kemudian dapat didistribusikan dalam bentuk ekstensi file .apk melalui LMS UNIKOM.

\section{PEMBAHASAN}

Pendidikan berfungsi sebagai melayani siswa dengan berbagai kemampuan dan keterbatasan di kelas pendidikan umum, dengan dukungan di kelas yang sesuai (Gaad \& Almotairi, 2013). Dari penjelasan di atas dapat diartikan pembelajaran adalah hak bagi seluruh anak. Kemampuan dan keterbatasan bagi anak berkebutuhan khusus tidak luput dari hak untuk mendapatkan Pendidikan.

Anak berkebutuhan khusus merupakan anak yang berperilaku menyimpang dari ratarata anak normal biasanya. Dalam hal, mental, kemampuan sensorik, fisik dan neuromuskular, sosial dan emosional perilaku, keterampilan komunikasi, serta kombinasi dari dua atau lebih hal tersebut (WitaHarahap \& Surya, 2017). Oleh karena itu kesetaraan dan pemerataan dalam pendidikan perlu diperkuat dan didukung untuk diperlukannya memberikan perhatian dan perhatian kepada semua termasuk siswa berkebutuhan khusus (Padmadewi \& Artini, 2017). Karena keterbatasan tersebut harus dibantu dengan alternatif pembelajaran.

Penanganan anak berkebutuhan khusus atau dalam hal ini yaitu mahasiswa berkebutuhan khusus harus dibutuhkan perlakuan khususnya pula. Perlakuan khusus ini berupa tools ataupun produk yang dapat menunjang pembelajaran. Teknologi dapat dimanfaatkan sebagai sebuah penunjang proses pembelajaran. Maka dari itu diperlukan pembelajaran seluler adaptif. Pembelajaran seluler adaptif adalah sebuah aplikasi multimedia pembelajaran yang menyediakan materi pembelajaran Melalui perangkat seluler dan dapat menyesuaikan Menggabungkan karakteristik gaya belajar pengguna (gaya pembelajaran siswa) (Surahman \& Alfindasari, 2017). Penggunaan sebuah platform dapat mempromosikan pembelajaran berbagai karakteristik pelajar yang berbeda(Surahman, Kuswandi, Wedi, Zufar At Thaariq, \& Chulashotud Diana, 2020).

Saat ini, teknologi bisa menjadi peluang yang sangat berguna. Dalam bidang pendidikan, penggunaan smartphone dapat berguna untuk menunjang kegiatan belajar sepanjang hidup (Fitria \& Hamdu, 2021). Dengan alasan tersebut bahwasanya pembelajaran mobile yang pada umumnya, dianggap dapat meningkatkan prestasi pelajar dengan membuat pembelajaran dapat diakses dengan mudah (Ozdamli \& Cavus, 2011).

Pembelajaran seluler yang dikembangkan adalah untuk menunjang kesempatan yang sama untuk belajar dan untuk menyediakan akses kapan saja, tanpa penghalang berupa tempat, ataupun jarak (Ally \& Prieto-Blázquez, 2014). Pembelajaran tersebut sangat berguna bagi peserta didik dan tenaga pengajar dalam proses pembelajaran. Diperlukannya juga media pembelajaran untuk membantu pembelajaran yang dilakukan lewat seluler atau mobile. Mobile learning atau pembelajaran seluler dapat diartikan sebagai model pembelajaran yang dapat diakses menggunakan perangkat berbasis mobile (Martha, Adi, \& Soepriyanto, 2018). Model pembelajaran seluler untuk kebutuhan pembelajaran khusus dapat digunakan sebagai panduan pengembangan untuk menghasilkan 
aplikasi pembelajaran seluler yang dapat digunakan yang mencakup berbagai tingkat keparahan (Ping, Dennis, Julaihi, \& Boon, n.d.).

Smartphone atau ponsel pintar pada dasarnya sudah banyak digunakan pada lingkungan khususnya sekitar UNIKOM. Hampir setiap mahasiswa memiliki smartphone mobile, yang kebanyakan smartphone bersistem operasi android. Menggunakan smartphone sebagai media pembelajaran tidak hanya memungkinkan peserta didik untuk mengembangkan pembelajaran melalui pencarian informasi di internet atau hanya sekedar menggunakan aplikasi smartphone, tetapi juga memungkinkan peserta didik untuk melatih keterampilan mereka dalam berlatih dengan prinsip mobilitas mereka(Ismanto, Novalia, \& Herlandy, 2017).

Media pembelajaran adalah seperangkat alat yang dapat membantu dan melengkapi guru atau pendidik untuk mencapai proses belajar yang baik dan benar bersama peserta didik (Sutiah \& Supriyono, 2020). Dalam hal ini media pembelajaran seharusnya dapat membantu peserta didik dan tenaga pengajar dalam proses pembelajaran. Dengan begitu pembelajaran dapat berjalan dengan baik. Selain itu juga diharapkan media pembelajaran harus menjadi lebih menarik dan memudahkan bagi mahasiswa, khususnya mahasiswa berkebutuhan khusus.

Media dalam pembelajaran memiliki kegunaan yaitu, penyampaian yang dilakukan oleh tenaga pengajar berupa materi pelajaran dapat disatukan, lebih mudah dimengerti dan menarik atau dibuat dengan beragam animasi Semakin interaktif dalam melakukan proses pembelajaran, penggunaan waktu serta tenaga menjadi lebih efisien, Siswa melakukan pembelajaran dengan output berupa hasil belajar dapat meningkatkan kualitasnya, Proses belajar dapat dilakukan tanpa batas tempat dan waktu melalui penggunaan media. Serta bisa menghidupkan sikap yang baik bagi siswa pada materi serta proses belajar, dan juga guru menjadi semakin berperan kearah yang semakin baik dan produktif (Karo-Karo \& Rohani, 2018)

Pemanfaatan mobile learning atau pembelajaran seluler yang berbasis android digunakan dengan menjadikannya sebagai pendamping atau alternatif dalam pembelajaran mata kuliah laboratorium pemrograman dasar kemudian diunggah ke dalam LMS. Selain itu juga, penggunaan perangkat android juga sudah cukup luas, atas dasar inilah android dipilih sebagai mobile learning (Liliarti \& Kuswanto, 2018). Aplikasi yang dibangun memuat materi tentang mata kuliah laboratorium pemrograman dasar. Mata kuliah ini merupakan mata kuliah yang menekankan pada praktikum penggunaan Bahasa C. Dan mata kuliah ini adalah mata kuliah yang wajib diikuti mahasiswa program studi sistem informasi. Mata kuliah ini sangat terkait erat dengan algoritma pemrograman dasar. perbedaannya algoritma pemrograman dasar menjelaskan teori, sedangkan laboratorium pemrograman dasar lebih kepada praktikum.

Kemampuan untuk menggunakan atau mengimplementasikan syntax Bahasa $\mathrm{C}$ merupakan kemampuan utama dalam mata kuliah laboratorium pemrograman dasar, kemampuan tersebut juga menjadi tolak ukur pada mata kuliah laboratorium pemrograman dasar. Karena kemampuan tersebut merupakan kemampuan yang harus dimiliki untuk mengikuti mata kuliah ke jenjang selanjutnya adalah melalui mata kuliah ini. Walaupun pada dasarnya trend penggunaan Bahasa $\mathrm{C}$ pada tahun 2016 mengalami penurunan sebesar 6\% (Kumar $\&$ Dahiya, 2017). Namun penggunaan Bahasa $C$ sebagai bahasa pemrograman tingkat dasar dirasa cukup relevan. Pemanfaatan teknologi dalam pembelajaran pada UNIKOM yaitu menggunakan LMS. LMS merupakan sistem yang saling terhubung dan menyeluruh yang dapat digunakan dalam platform e-learning (Trivedi, Mohd, \& Sharma, 2013). Teknologi tersebut digunakan demi menunjang pembelajaran bagi mahasiswa ataupun mahasiswa berkebutuhan khusus dibutuhkan mobile learning.

Pada penelitian penelitian yang dilakukan oleh (Hardiyana, Fadilah, \& Effendi, 2020) didapatkan hasil pengujian dan kuesioner dengan nilai sebesar $85 \%$. Dimana penggunaan aplikasi berbasis multimedia pada subjek anak berkebutuhan khusus dapat meningkatkan minat pembelajaran materi pembelajaran linked list algorithm. Dapat disimpulkan dari penggunaan 
286 JINOTEP (Jurnal Inovasi dan Teknologi Pembelajaran) Kajian dan Riset dalam Teknologi Pembelajaran Vol.8, No.3, November 2021, Hal. 277-288

multimedia pada aplikasi pembelajaran menjadi lebih efektif dan cocok untuk anak berkebutuhan khusus.

Penelitian yang serupa dengan penelitian ini yang selanjutnya yaitu penelitian yang dilakukan oleh (Effendi, Hardiyana, \& Gustiana, 2016). Dimana subjek penelitian memiliki kesamaan yaitu Anak berkebutuhan khusus namun terdapat perbedaan, pada penelitian tersebut pada anak berkebutuhan khusus yang tergolong tunarungu sedangkan pada penelitian ini tergolong pada autism tingkat satu atau tingkat rendah.

Aplikasi pembelajaran multimedia laboratorium pemrograman dasar yang dibuat ini memperoleh hasil validasi dari ahli media senilai $84 \%$, ahli materi sebesar $80 \%, 79 \%$ ahli disabilitas dan mahasiswa MBK sebesar $81 \%$ serta mahasiswa reguler sebesar $86 \%$. Nilai tersebut termasuk memenuhi standar dari ahli media, ahli materi ahli disabilitas dan mahasiswa serta mahasiswa berkebutuhan khusus yang mengikuti mata kuliah laboratorium pemrograman dasar. Berdasarkan kriteria dari berbagai pengujian dari para ahli maupun mahasiswa didapatkan dari nilai diatas dapat dikatakan valid. Hasil diatas menunjukkan pula penggunaan multimedia masih efektif dalam media pembelajaran khususnya untuk mahasiswa berkebutuhan khusus.

\section{SIMPULAN}

Aplikasi Multimedia pembelajaran mata kuliah laboratorium pemrograman dasar adalah aplikasi yang digunakan untuk mahasiswa, khususnya mahasiswa berkebutuhan khusus yang tergolong autism level satu. Aplikasi ini merupakan alternatif pembelajaran yang kemudian dapat membantu mahasiswa khususnya mahasiswa berkebutuhan khusus dalam memahami materi laboratorium pemrograman dasar dan juga diharapkan minat belajar mahasiswa berkebutuhan khusus dapat meningkat dan lebih mudah dipahami oleh mahasiswa, khususnya mahasiswa berkebutuhan khusus. Aplikasi ini nantinya akan diunggah pada LMS UNIKOM untuk mata kuliah laboratorium pemrograman dasar berbasis android dengan ekstensi aplikasi yaitu .apk. Dari hasil analisis didapatkan bahwasanya aplikasi ini tergolong valid dengan nilai kevalidan diatas $79 \%$. Ahli media memberikan nilai validasi sebesar $84 \%$, nilai validasi ahli materi sebesar $80 \%$, dan nilai validasi $79 \%$ berasal dari ahli disabilitas serta pengujian aplikasi yang diujicobakan kepada mahasiswa mendapatkan nilai validasi sebesar $86 \%$ dan terakhir yaitu $81 \%$ berasal dari mahasiswa berkebutuhan khusus, dan dapat digunakan sebagai alternatif pembelajaran guna membantu mahasiswa berkebutuhan khusus memahami materi laboratorium pemrograman dasar pada program studi sistem informasi UNIKOM.

\section{DAFTAR RUJUKAN}

Akbarini, N. R., Murtini, W., \& Rahmanto, A. N. (2018). Design of interactive learning multimedia development in general administration subject. International Journal of Multicultural and Multireligious Understanding, $\quad 5(4), \quad 138-148$. doi:https://doi.org/10.18415/ijmmu.v5i4.218

Ally, M., \& Prieto-Blázquez, J. (2014). What is the future of mobile learning in education? International Journal of Educational Technology in Higher Education, 11(1), 142151.

Ambiyar, A., \& Dewi, M. (2019). Metodologi Penelitian Evaluasi Program. Alfabeta.

Astuti, P. (2018). Penggunaan Metode Black Box Testing (Boundary Value Analysis) Pada Sistem Akademik (SMA/SMK). Faktor Exacta, 11(2), 186-195. doi:https://doi.org/10.30998/faktorexacta.v11i 2.2510

Budiaji, W. (2013). Skala pengukuran dan jumlah respon skala likert. Jurnal Ilmu Pertanian Dan Perikanan, 2(2), 127-133.

Djamaluddin, A. (2014). Filsafat Pendidikan. Istiqra: Jurnal Pendidikan Dan Pemikiran Islam, 1(2), 129-135.

Effendi, D., Hardiyana, B., \& Gustiana, I. (2016). Perancangan program aplikasi pembelajaran ipa materi sistem pernapasan berbasis multimedia untuk siswa sdlb bagian $b$ tuna rungu menggunakan object oriented approach. Simetris: Jurnal Teknik Mesin, Elektro Dan Ilmu Komputer, 7(2), 605-618. doi:https://doi.org/10.24176/simet.v7i2.773

Fadillah, I. Y., Hardiyana, B., \& Dhaniawaty, R. P. (2021). Perancangan Game Edukasi "The Legend of Al-Khawarizmi” sebagai Alat Bantu Pembelajaran Mahasiswa Berkebutuhan Khusus. Jurnal Pendidikan Kebutuhan Khusus, 5(2), 103-111.

Fitria, A., \& Hamdu, G. (2021). Pengembangan 
Aplikasi Mobile Learning untuk Perangkat Pembelajaran Berbasis Education for Sustainable Development. JINOTEP (Jurnal Inovasi Dan Teknologi Pembelajaran): Kajian Dan Riset Dalam Teknologi Pembelajaran, $8(2)$, 134-145. doi:https://doi.org/10.17977/um031v8i22021p 134

Gaad, E., \& Almotairi, M. (2013). Inclusion of student with special needs within higher education in UAE: Issues and challenges. Journal of International Education Research (JIER), 9(4), 287-292. doi:https://doi.org/10.19030/jier.v9i4.8080

Gunawan, G. (2015). Model Pembelajaran Sains berbasis ICT. FKIP Universitas Mataram.

Hardiyana, B., Fadilah, L., \& Effendi, D. (2020). Application of Linked List Algorithm Based on Multimedia. In IOP Conference Series: Materials Science and Engineering (Vol. 879, p. 12087). IOP Publishing. doi:https://doi.org/10.19030/jier.v9i4.8080

Ismanto, E., Novalia, M., \& Herlandy, P. B. (2017). Pemanfaatan smartphone android sebagai media pembelajaran bagi guru SMA Negeri 2 kota Pekanbaru. Jurnal Pengabdian UntukMu NegeRI, 1(1), 42-47. doi:https://doi.org/10.37859/jpumri.v1i1.33

Kaewkiriya, T. (2013). A design and development of e-learning content for multimedia technology using multimedia game. International Journal of Software Engineering \& Applications, 4(6), 61-69.

doi:https://doi.org/10.5121/ijsea.2013.4606

Karo-Karo, I. R., \& Rohani, R. (2018). Manfaat media dalam pembelajaran. AXIOM: Jurnal Pendidikan Dan Matematika, 7(1), 91-96. doi:https://doi.org/10.30821/axiom.v7i1.1778

Kumar, K., \& Dahiya, S. (2017). Programming languages: A survey. International Journal on Recent and Innovation Trends in Computing and Communication, 5(5), 307-313.

Lee, W., \& Owens, D. (2004). Multimedia-based Instructional Design. San Francisco, USA: Pfeiffer. John Wiley \& Son Inc.

Liliarti, N., \& Kuswanto, H. (2018). Improving the Competence of Diagrammatic and Argumentative Representation in Physics through Android-Based Mobile Learning Application. International Journal of Instruction, 11(3), 107-122. doi:https://doi.org/10.12973/iji.2018.1138a

Martha, Z. D., Adi, E. P., \& Soepriyanto, Y. (2018). E-book berbasis Mobile learning. Jurnal Kajian Teknologi Pendidikan, 1(2), 109-114.

Nasibulina, A. (2017). Education for sustainable development. In Advances in Human Factors, Business Management, Training and Education (pp. 947-954). Springer. doi:https://doi.org/10.1007/978-3-319-42070-

\section{7}

Ozdamīi, F., \& Cavus, N. (2011). Basic elements and characteristics of mobile learning. ProcediaSocial and Behavioral Sciences, 28, 937-942. doi:https://doi.org/10.1016/j.sbspro.2011.11.1 73

Padmadewi, N. N., \& Artini, L. P. (2017). Teaching English to a Student with Autism Spectrum Disorder in Reguler Classroom in Indonesia. International Journal of Instruction, 10(3), 159-176. doi:https://doi.org/10.12973/iji.2017.10311a

Ping, T. P., Dennis, P. S., Julaihi, A. A., \& Boon, M. G. (n.d.). Mobile Learning Model for Children with Special Learning Needs.

Praherdhiono, H. (2014). Convenience of Learning Environment for Student Special Education With Cyberwellness Concept. Proceeding International Postdraduate University Kebangsaan Malaysia. SEAMOSEN.

Purwanto, A., \& Hanief, S. (2016). Multimedia Pembelajaran Bahasa Indonesia Untuk Mahasiswa Berbasis Animasi. SEMNASTEKNOMEDIA ONLINE, 4(1), 4-8.

Sambung, D., Sihkabuden, S., \& Ulfa, S. (2018). Pengembangan Mobile Learning Berbasis Gamifikasi Untuk Penguasaan Kosakata Bahasa Jepang Kelas X Sman 1 Garum. JINOTEP (Jurnal Inovasi Dan Teknologi Pembelajaran): Kajian Dan Riset Dalam Teknologi Pembelajaran, 3(2), 121-129.

Shi, X. (2017). Application of Multimedia Technology in Vocabulary Learning for Engineering Students. International Journal of Emerging Technologies in Learning, 12(1), 2131 . doi:https://doi.org/10.3991/ijet.v12i01.6153

Surahman, E., \& Alfindasari, D. (2017). Developing Adaptive Mobile Learning with the Principle of Coherence Mayer on Biology Subjects of High School to Support the Open and Distance Education. In Proceedings of the $3 \mathrm{rd}$ International Conference on Education and Training (ICET 2017). Paris, France: Atlantis Press. doi:10.2991/icet-17.2017.31

Surahman, E., Kuswandi, D., Wedi, A., Zufar At Thaariq, Z., \& Chulashotud Diana, R. (2020). Model Design of Adaptive Learning Analytics Management System (ALAMS) Using AID Model. In Proceedings of the 4th International Conference on Education and Management (COEMA 2019) (Vol. 5, pp. 413-430). Paris, France: Atlantis Press. doi:10.2991/coema19.2019.15

Sutiah, S., \& Supriyono, S. (2020). Software Testing on The Learning of Islamic Education Media Based on Information Communication Technology Using Blackbox Testing. IJISTECH (International Journal of Information System \& Technology), 3(2), 254- 
288 JINOTEP (Jurnal Inovasi dan Teknologi Pembelajaran) Kajian dan Riset dalam Teknologi Pembelajaran Vol.8, No.3, November 2021, Hal. 277-288

260.

Trivedi, R. K., Mohd, N., \& Sharma, R. (2013). Proposed framework for open source based elearning implementation in Uttarakhand. International Journal of Engineering Research \& Technology, 2(11), 2270-2279.
WitaHarahap, L., \& Surya, E. (2017). Development of learning media in mathematics for students with special needs. International Journal of Sciences: Basic and Applied Research (IJSBAR), 33(3), 1-12. 